\title{
BYPRODUCTS OF PRODUCTION OF RICE GOOD RAW MATERIAL FOR ANIMAL PRODUCTION IN MACEDONIA
}

\author{
Dobre Andov $^{1}$, Danica Andreevska ${ }^{1}$, Vladimir Medarski ${ }^{2}$ \\ ${ }^{1}$ Ss. Cyril and Methodius University in Skopje, Agricultural Institute, Skopje, \\ Department of Rice - Kočani, Nikola Karev No. 8, Republic of Macedonia \\ ${ }^{2}$ The Agency for Development of the Agriculture of Republic of Macedonia, Bitola, PE Kočani \\ dr_andov@yahoo.com
}

\begin{abstract}
Before starting with the organization of vegetable or animal production it is necessary an identification of the required conditions and raw materials to be made. The secondary products of rice used as raw materials for animal production until now have not been worked on enough in the Republic of Macedonia. In this work it will be presented and analyzed the results of the examination (twenty years long average) of the seeded areas, the production of paddy rice, straw and the secondary products with the reproduction of paddy rice (hull and bran). The yield of straw in sorts is established in field experiments, and the quantity of hull and bran are calculated according to the percentage that has been obtained with the laboratory analysis. In Macedonia the rice is maintained on 4189 ha of area and prevailing sorts are: Monticeli (2 471ha), r-76/6 (1 381ha), San Andrea (1 301ha) and Prima riska (392ha). The results of the examinations show that yearly the average production is 19157 tons of paddy rice, 37411 tons of straw, 3615 tons of hull and 2067 tons of bran. The results of this work are going to have first of all a practical use for the existing and future farmers for the superior potential of the raw materials of rice production in animal production.
\end{abstract}

Key words: paddy rice; straw; hull; bran; raw materials; animal production

\section{СПОРЕДНИТЕ ПРОИЗВОДИ ОД ПРОИЗВОДСТВОТО НА ОРИЗ - ДОБРА СУРОВИНА ЗА СТОЧАРСТВОТО ВО МАКЕДОНИЈА}

\begin{abstract}
Пред започнување со растително или сточарско производство потребно е да се направи идентификација на потребните услови и суровини за тоа производство. На споредните производи од одгледувањето на ориз како суровина за сточарското производство досега кај нас не е обрнувано доволно вномание. Во овој труд се презентирани и анализирани резултатите од истражувањето (дваесетгодишен просек) на засеаните површини, на производството на суров ориз (арпа), оризова слама и споредни производи добиени при преработката на арпата (оризови лушпи и трици). Приносот на слама по сорти е утврден во полски експерименти, а количините на оризови лушпи и трици се пресметани според процентот добиен со лабораториска анализа. Во Македонија оризот е застапен во просек на површина од 4189 hа, при што водечки сорти се: мониичели (2471 ha), p-76/6 (1381 ha), сан андреа (1301 ha) и ирима риска (392 ha). Резултатите од истражувањата покажуваат дека просечно годишно се произведуваат 19157 тони оризова арпа, 37411 тони слама, 3615 тони лушпи и 2067 тони оризова плева. Резултатите од овој труд ќе имаат пред сѐ практична примена кај сегашните и идни фармери за користење на расположливиот потенцијал на суровините од оризопроизводството во сточарството.
\end{abstract}

Клучни зборови: оризова арпа; слама; лушпи; трици; суровина; сточарско производство

\section{INTRODUCTION}

Rice (Oryza sativa L.) is one of the oldest agricultural plants. It was well knawn long time ago for the people of East Asia, 7000 years BC. It originates from south-east Asia, from whereas is transmitted and spread all over the world (Boaksen and Suja, 1984).

Today it is grown on all the continents and is main diet for the human population in the world. 
The rice will continue to be the main source of food in future. It is mostly grown in Asia, where it is the main food for $60 \%$ of the population.

Even though the rice is not main diet for the people from the Republic of Macedonia, it is an important agricultural plant because it is a crop harvested as unpeeled grain and other new products per unit. As an agricultural plant the rice is of big importance, because it provides high crops harvest on fields where other grains are less successful.

The production of rice in Macedonia is mainly concentrated in the east region, in the area of Kočani, Štip, Vinica and Blatec.

Rice is the main source of food and that is why it is of huge importance as well as the products made of it such as broken rice, the rice straw, bran and the hulls.

In the scientific and specialized literature in this area so far the products made of rice are not processed well enough, and some are of big importance for the farming.

That is the reason why the main purpose of this work will be presenting and analyzing the results of (in average twenty years) the production of paddy rice and byproducts (straw, bran and hulls) in the Republic of Macedonia.

\section{MATERIAL AND METHODS}

The crop harvest of unpeeled rice (paddy rice) and straw classified according to the type, variety and years of production is confirmed with experiments proceeded on the fields at the time of crop.

The calculation of the quantity amount of the new products (products made of rice) is based on the crop harvest and the percentage obtained in the year of production. The percentage of byproducts (bran and hulls) made of the whole grain of rice with its preparation is defined with the laboratory peeler for each variety separately.

\section{RESULTS AND DISCUSSION}

\section{Planted areas, average yields and total production of rice in Macedonia}

In Table 1 the results of planted areas, the average yields and the total production of rice in the Republic of Macedonia are shown for the period from 1989 to 2008 year. This table shows that the average areas planted with rice are 4189 ha, and the largest surfaces with rice were planted in 1990 (8880 ha) and the smallest in 1994 (1200 ha).

The highest average yield of paddy rice is achieved in $2003(6500 \mathrm{~kg} / \mathrm{ha})$ and the lowest in $1993(1830 \mathrm{~kg} / \mathrm{ha})$. The average crop harvest is $4744 \mathrm{~kg} / \mathrm{ha}$.

The total production of paddy rice for the period analyzed amounts on average to 19143 tons (6120 in 1994 and 42000 tons in 1992).

\section{Table 1}

Planted areas, average yields and total production of rice in Macedonia

\begin{tabular}{cccc}
\hline \hline Year & Areas & $\begin{array}{c}\text { Average yield } \\
\text { of paddy rice } \\
\text { (kg/ha) }\end{array}$ & $\begin{array}{c}\text { Total production } \\
\text { of paddy rice } \\
\text { (tons) }\end{array}$ \\
\hline 1989 & 6056 & 4536 & 27675 \\
1990 & 8880 & 3100 & 27386 \\
1991 & 8692 & 4314 & 37497 \\
1992 & 8465 & 5000 & 42000 \\
1993 & 3500 & 1830 & 6420 \\
1994 & 1200 & 5100 & 6120 \\
1995 & 1316 & 5200 & 6843 \\
1996 & 4800 & 5300 & 25440 \\
1997 & 5500 & 3600 & 19800 \\
1998 & 3905 & 4800 & 18744 \\
1999 & 3455 & 4870 & 16825 \\
2000 & 4510 & 4530 & 20430 \\
2001 & 1978 & 4200 & 8307 \\
2002 & 2450 & 4500 & 11025 \\
2003 & 3962 & 6500 & 25753 \\
2004 & 3870 & 5000 & 19350 \\
2005 & 2700 & 5500 & 14850 \\
2006 & 2886 & 6000 & 17316 \\
2007 & 2853 & 5000 & 14265 \\
2008 & 2800 & 6000 & 16800 \\
\hline Average & 4189 & 4744 & 19143 \\
\hline \hline
\end{tabular}

\section{Areas of rice per years and per varieties}

The existing varieties of rice in rice productions and planted areas change every year according to the production and they mainly affect the entire crop harvest of rice and products made of it. During the past period of rice production in our 
country varieties of introduction (mostly Italian and Bulgarian) and home local sorts were spead.

According to the results shown in Table 2 it can be seen that during the analyzed period on the largest areas the sort Montichelli (2471 ha) was mostly represented. The largest areas of this variety (Montichelli) were planted in 1992 (6727 ha).
During this period the fields planted with the variety Montichelli are dramatically decreasing and the main part of the area is planted with the varieties San Andrea (1301 ha) and R-76/6 (1381 ha). Of domestic varieties Prima riska (392 ha) is planted on the largest areas and the variety biser-2 (36 ha) is planted on the smallest areas.

Table 2

Areas of rice per years and per varieties (ha)

\begin{tabular}{|c|c|c|c|c|c|c|c|c|}
\hline \multirow[b]{2}{*}{ Year } & \multicolumn{7}{|c|}{ Varieties } & \multirow{2}{*}{ Total } \\
\hline & Monticeli & $R-76 / 6$ & Osogovka & Kočanski & Biser-2 & San Andrea & Prima riska & \\
\hline 1989 & 2156 & 3587 & 218 & 90 & - & - & - & 6051 \\
\hline 1990 & 5209 & 3300 & 197 & 131 & 41 & - & - & 8878 \\
\hline 1991 & 5434 & 2942 & 162 & 108 & 44 & - & - & 8690 \\
\hline 1992 & 6727 & 1738 & - & - & - & - & - & 8465 \\
\hline 1993 & 2077 & 1386 & - & - & 37 & - & - & 3500 \\
\hline 1994 & 921 & 259 & - & - & 20 & - & - & 1200 \\
\hline 1995 & 567 & 749 & - & - & - & - & - & 1316 \\
\hline 1996 & 2789 & 2011 & - & - & - & - & - & 4800 \\
\hline 1997 & 2798 & 2702 & - & - & - & - & - & 5500 \\
\hline 1998 & 3181 & 566 & - & - & - & 157 & - & 3904 \\
\hline 1999 & 3053 & 350 & - & - & - & 52 & - & 3455 \\
\hline 2000 & 2729 & 877 & - & - & - & 929 & - & 4535 \\
\hline 2001 & 1190 & 344 & - & - & - & 443 & - & 1977 \\
\hline 2002 & - & 1541 & - & - & - & 908 & - & 2449 \\
\hline 2003 & - & - & - & - & - & 3962 & - & 3962 \\
\hline 2004 & 1290 & - & - & - & - & 2580 & - & 3870 \\
\hline 2005 & - & 519 & - & - & - & 1090 & 1090 & 2699 \\
\hline 2006 & 422 & 488 & - & - & - & 1643 & 333 & 2886 \\
\hline 2007 & 535 & 775 & - & - & - & 1494 & 49 & 2853 \\
\hline 2008 & 930 & 719 & - & - & - & 1054 & 96 & 2799 \\
\hline Average & 2471 & 1381 & 192 & 110 & 36 & 1301 & 392 & 4189 \\
\hline
\end{tabular}

\section{Production of paddy rice per years and per varieties}

The production of paddy rice per years and per varieties is shown in Table 3. From the table the average production of paddy rice can be seen for the period of twenty years and amounts to 19157 tons and varies from 6120 tons (in 1994) to 42325 tons (in 1992).
The highest average production of paddy rice is received from the variety Montichelli (10826 t), on the second place is San Andrea (7224 t), on the third $R-76 / 6$ with average production of $5932 \mathrm{t}$. The lowest average production of paddy rice for the analyzed period is obtained from the variety Biser-2 (122 t). 
Table 3

Production of paddy rice per years and per varieties ( $t)$

\begin{tabular}{ccccccccc}
\hline \hline Year & & \multicolumn{7}{c}{ Varieties } \\
& Monticeli & $R-76 / 6$ & Osogovka & Kočanski & Biser-2 & San Andrea & Prima riska & Total \\
\hline 1989 & 9780 & 16271 & 989 & 408 & - & - & - & 27448 \\
1990 & 16148 & 10230 & 611 & 406 & 127 & - & - & 27522 \\
1991 & 23442 & 12692 & 699 & 466 & 190 & - & - & 37489 \\
1992 & 33635 & 8690 & - & - & - & - & - & 42325 \\
1993 & 3801 & 2536 & - & - & 68 & - & - & 6405 \\
1994 & 4697 & 1321 & - & - & 102 & - & - & 6120 \\
1995 & 2948 & 3895 & - & - & - & - & - & 6843 \\
1996 & 14782 & 10658 & - & - & - & - & - & 25440 \\
1997 & 10073 & 9727 & - & - & - & - & - & 19800 \\
1998 & 15269 & 2717 & - & - & - & 754 & - & 18740 \\
1999 & 14868 & 1705 & - & - & - & 253 & - & 16826 \\
2000 & 12362 & 3973 & - & - & - & 4208 & - & 20543 \\
2001 & 4998 & 1445 & - & - & - & 1861 & - & 8304 \\
2002 & - & 6935 & - & - & - & 4086 & - & 11021 \\
2003 & - & - & - & - & - & 25753 & - & 25753 \\
2004 & 6450 & - & - & - & - & 12900 & - & 19350 \\
2005 & - & 2855 & - & - & - & 5995 & 5995 & 14845 \\
2006 & 2532 & 2928 & - & - & - & 9858 & 1998 & 17316 \\
2007 & 2675 & 3875 & - & - & - & 7470 & 245 & 14265 \\
2008 & 5580 & 4314 & - & - & - & 6324 & 576 & 16794 \\
Average & 10826 & 5932 & 766 & 427 & 122 & 7224 & 2204 & 19157 \\
\hline \hline & & & & & & & &
\end{tabular}

\section{Production of straw of rice per years and per varieties}

The rice straw is used in animals diets, for preparation of silages with some fodder plants such as alfalfa, forage pea, chickling. Straw is good for the paper industry and is used in the mushroom production and preparation as well as in plantation production.

The recieved amount of straw mostly depends on the variety and the use of agrotechnic on higher amounts of manure and it increases the production of rice straw per unit (Bojadžieva, 1981; Andreevska et al., 2000, 2004, 2005/2006, 2007; Ilieva et al., 1999, 2005/2006).

Table 4 shows that the average production of rice straw for the period of twenty years amounts to 37411 tons, and varies from 11334 tons (in
1994) to 77984 tons (in 1992). The average production of rice straw classified per varieties amount to Montichelli - 19129 t, San Andrea $15351 \mathrm{t}, R-76 / 6-12663 \mathrm{t}$ and Biser-2 - $255 \mathrm{t}$.

\section{Production of hulls of rice per years and per varieties}

According to Rutger (1975) unpeeled (paddy) rice with preparation gives around $20 \%$ hulls, $8 \%$ bran, $2 \%$ for polishing and $70 \%$ white rice.

Because the rice paddy grain is enveloped in glumes it is not suitable for eating. That is why, to eliminate them, during the post-harvesting processing there are factories (mills) that are completely equipped with special machines for each operation. 
Table 4

Production of straw of rice per years and per varieties $(t)$

\begin{tabular}{ccccccccc}
\hline \hline & \multicolumn{7}{c}{ Varieties } & \\
\cline { 2 - 7 } Year & Monticeli & $R-76 / 6$ & Osogovka & Kočanski & Biser-2 & San Andrea & Prima riska & Total \\
\hline 1989 & 17281 & 34735 & 1837 & 695 & - & - & - & 54584 \\
1990 & 28534 & 21839 & 1135 & 691 & 266 & - & - & 52465 \\
1991 & 41422 & 27095 & 1298 & 793 & 398 & - & - & 71006 \\
1992 & 59433 & 18551 & - & - & - & - & - & 77984 \\
1993 & 6716 & 5414 & - & - & 143 & - & - & 12273 \\
1994 & 8300 & 2820 & - & - & 214 & - & - & 11334 \\
1995 & 5209 & 8315 & - & - & - & - & - & 13524 \\
1996 & 26120 & 22753 & - & - & - & - & - & 48873 \\
1997 & 17799 & 20765 & - & - & - & - & - & 38564 \\
1998 & 26981 & 5800 & - & - & - & 1602 & - & 34383 \\
1999 & 26272 & 3640 & - & - & - & 538 & - & 30450 \\
2000 & 21844 & 8482 & - & - & - & 8942 & - & 39268 \\
2001 & 8832 & 3085 & - & - & - & 3955 & - & 15872 \\
2002 & - & 14805 & - & - & - & 8683 & - & 23488 \\
2003 & - & - & - & - & - & 54725 & - & 54725 \\
2004 & 11397 & - & - & - & - & 27412 & - & 38809 \\
2005 & - & 6095 & - & - & - & 12739 & 12739 & 31573 \\
2006 & 4474 & 6251 & - & - & - & 20948 & 4246 & 35919 \\
2007 & 4727 & 8272 & - & - & - & 15874 & 521 & 29394 \\
2008 & 9860 & 9210 & - & - & - & 13439 & 1224 & 33733 \\
\hline Average & 19129 & 12663 & 1423 & 726 & 255 & 15351 & 4683 & 37411 \\
\hline \hline
\end{tabular}

The percentage of hulls by Milev (1968) is variety characteristic and it is needed into normal (regular) soil and climate conditions.

The amount of rice products with the procedure of milling the paddy rice varies a lot with different varieties grown in different regions and conditions (different terms of planting, one side manurring, unproporcional procedure of irrigation).

Table 5 presents the results of rice hulls production per years and per varieties. This table shows that the whole average production of rice hulls amounts to 3615 tones, and varies from 1153 tons (1994) to 7965 tons (1992). The average amount of rice hulls is: Montichelli - 2035 t, San Andrea - 1373 t, R-76/6 - $1121 \mathrm{t}$ and Biser-2 $24 \mathrm{t}$.

\section{Production of bran of rice per years and per varieties}

The rice bran is a solid base for making concentrates for food for domestic animals.

From the results shown in Table 6 it can be summed up that the whole average production of rice bran for the period analyzed is $2067 \mathrm{t}$, where the highest crop harvest is confirmed in 1992 (4563 t) and the smallest in 1994 (659 t).

If we analyze the harvest according to the varieties it can be seen that the highest average income is confirmed with the sort Montichelli (1169 $\mathrm{t}$ ), and the lowest with the sort - Biser -2 (13 t).

According to the researches by Andov (1999, 2003) the varieties with higher percentage of proteins are more resistant than the procedure of milling and they give less rice bran. 
Table 5

Production of hulls of rice per years and per varieties ( $t$ )

\begin{tabular}{|c|c|c|c|c|c|c|c|c|}
\hline \multirow[t]{2}{*}{ Year } & \multicolumn{7}{|c|}{ Varieties } & \multirow{2}{*}{ Total } \\
\hline & Monticeli & $R-76 / 6$ & Osogovka & Kočanski & Biser-2 & San Andrea & Prima riska & \\
\hline 1989 & 1839 & 3075 & 198 & 78 & - & - & - & 5190 \\
\hline 1990 & 3036 & 1933 & 122 & 78 & 25 & - & - & 5194 \\
\hline 1991 & 4407 & 2399 & 140 & 89 & 38 & - & - & 7073 \\
\hline 1992 & 6323 & 1642 & - & - & - & - & - & 7965 \\
\hline 1993 & 715 & 479 & - & - & 14 & - & - & 1208 \\
\hline 1994 & 883 & 250 & - & - & 20 & - & - & 1153 \\
\hline 1995 & 554 & 736 & - & - & - & - & - & 1290 \\
\hline 1996 & 2779 & 2014 & - & - & - & - & - & 4793 \\
\hline 1997 & 1894 & 1838 & - & - & - & - & - & 3732 \\
\hline 1998 & 2871 & 514 & - & - & - & 143 & - & 3527 \\
\hline 1999 & 2795 & 322 & - & - & - & 48 & - & 3165 \\
\hline 2000 & 2324 & 751 & - & - & - & 800 & - & 3875 \\
\hline 2001 & 940 & 273 & - & - & - & 354 & - & 1567 \\
\hline 2002 & - & 1311 & - & - & - & 776 & - & 2087 \\
\hline 2003 & - & - & - & - & - & 4893 & - & 4893 \\
\hline 2004 & 1213 & - & - & - & - & 2451 & - & 3664 \\
\hline 2005 & - & 540 & - & - & - & 1139 & 1109 & 2788 \\
\hline 2006 & 476 & 553 & - & - & - & 1873 & 370 & 3272 \\
\hline 2007 & 503 & 732 & - & - & - & 1419 & 45 & 2699 \\
\hline 2008 & 1049 & 815 & - & - & - & 1202 & 107 & 3173 \\
\hline Average & 2035 & 1121 & 153 & 82 & 24 & 1373 & 408 & 3615 \\
\hline
\end{tabular}

Table 6

Production of bran of rice per years and per varieties ( $t$ )

\begin{tabular}{|c|c|c|c|c|c|c|c|c|}
\hline \multirow{2}{*}{ Year } & \multicolumn{7}{|c|}{ Varieties } & \multirow{2}{*}{ Total } \\
\hline & Monticeli & $R-76 / 6$ & Osogovka & Kočanski & Biser-2 & San Andrea & Prima riska & \\
\hline 1989 & 1056 & 1741 & 129 & 51 & - & - & - & 2977 \\
\hline 1990 & 1744 & 1095 & 79 & 51 & 13 & - & - & 2982 \\
\hline 1991 & 2532 & 1358 & 91 & 58 & 20 & - & - & 4059 \\
\hline 1992 & 3633 & 930 & - & - & - & - & - & 4563 \\
\hline 1993 & 411 & 271 & - & - & 7 & - & - & 689 \\
\hline 1994 & 507 & 141 & - & - & 11 & - & - & 659 \\
\hline 1995 & 318 & 417 & - & - & - & - & - & 735 \\
\hline 1996 & 1596 & 1140 & - & - & - & - & - & 2736 \\
\hline 1997 & 1088 & 1041 & - & - & - & - & - & 2129 \\
\hline 1998 & 1649 & 291 & - & - & - & 79 & - & 2019 \\
\hline
\end{tabular}




\begin{tabular}{|c|c|c|c|c|c|c|c|c|}
\hline \multirow{2}{*}{ Year } & \multicolumn{7}{|c|}{ Varieties } & \multirow{2}{*}{ Total } \\
\hline & Monticeli & $R-76 / 6$ & Osogovka & Kočanski & Biser-2 & San Andrea & Prima riska & \\
\hline 1999 & 1606 & 182 & - & - & - & 27 & - & 1815 \\
\hline 2000 & 1335 & 425 & - & - & - & 442 & - & 2202 \\
\hline 2001 & 540 & 155 & - & - & - & 195 & - & 890 \\
\hline 2002 & - & 742 & - & - & - & 429 & - & 1171 \\
\hline 2003 & - & - & - & - & - & 2704 & - & 2704 \\
\hline 2004 & 697 & - & - & - & - & 1355 & - & 2052 \\
\hline 2005 & - & 305 & - & - & - & 629 & 809 & 1743 \\
\hline 2006 & 273 & 313 & - & - & - & 1035 & 270 & 1891 \\
\hline 2007 & 289 & 415 & - & - & - & 784 & 33 & 1521 \\
\hline 2008 & 603 & 462 & - & - & - & 664 & 78 & 1807 \\
\hline Average & 1169 & 635 & 100 & 53 & 13 & 758 & 298 & 2067 \\
\hline
\end{tabular}

\section{CONCLUSION}

According to the researches the following can be concluded:

- In Macedonia rice is planted on the average area of 4189 ha (period of analysis from 1989 to 2008).

- Mostly varieties in production are: Montichelli average area of 2471 ha, R-76/6 - 1381 ha, San Andrea - 1301 ha and Prima riska 392 ha.

- 19157 tons is the average production of paddy rice yearly.

-37411 tons is the average anual production of rice straw.

- By processing paddy rice on average $3615 \mathrm{t}$ hulls and $2067 \mathrm{t}$ rice bran are produced.

- The straw and byproducts of rice (hulls and bran) are important source for the animal production in Macedonia.

\section{REFERENCES}

[1] Andov D. (1997): Grain Yield and Protein Content in Paddy, Brown and White Rice of some Rice Verieties Grown as First and Second Crop. Yearbook of The Institute of Agriculture, Vol. XVII, 31-43. Skopje.

[2] Andreevska Danica, Andov D., Ilieva Verica, Spasenoski M. (2000): Influence of Time and Method of Nitrogen Fertilisation on the Yield and the Grain Protein Content of some Rice Verieties. Yearbook of The Institute of Agriculture, Vol. XX, 48-59. Skopje.
[3] Andov D., Najčevska Cvetanka, Andreevska Danica, Ilieva Verica (2003): White Rice Yield and Products Obtained during Paddy Rice De Hullling Depending on the Variety and Cultivation. Proceedings of Papers XXVIII Meeting "Faculty with Farmers" 2003, Vol. 11, 115125. Skopje.

[4] Andreevska Danica, Jekić M., Ilieva Verica, Andov D., (2004): Prolonged Activity Effects of Mineral Fertilizers on White Rice Yield and Rice Protein Content. Yearbook of the Institute of Agriculture, Skopje, Vol. XXII/XXIII, 129-139.

[5] Andreevska Danica, Ilieva Verica, Andov D., Zaseva Tanja (2005/2006): Effect of Foliar Split Application with Kristalon ${ }^{\mathrm{TM}}$ Special upon Yield and Dressing White Rice. Yearbook of the Institute of Agriculture, Skopje, Vol. XXIV/XXV, 61-73. Skopje.

[6] Andreevska Danica, Ilieva Verica, Andov D., Zaseva Tanja (2007): Effect of basic fertilization and split application with diferent nitrogen fertilizers upon yield and quality of Prima riska - recently developed rice variety. Yearbook of the Faculty of Agriculture, Goce Delčev University, Štip, Vol. VII, 87-96.

[7] Boaksen, H and Suja, C., (1984): Kina -7000 godini odgleduvanje na oriz. Glasnik na UNESKO, Dekemvri, Paris, France.

[8] Bojadžieva, N. (1981): Upotreba kompleksnih (NPK) đubriva za povećanje prinosa pirinča. Agrohemija, $\mathrm{N}^{\mathrm{o}} 1-$ 2, Beograd.

[9] Vasilevski, G. I., Nikolov, P. (1997): Oriz: proizvodstvo $i$ prerabotka. "Tribina Makedonska", s. 160; Biblioteka Agronauka, Skopje.

[10] Ilieva Verica, Najcevska Cvetanka, Andov D., Andreevska Danica, Tomeva Elizabeta (1999): Charakteristics of some new hibrid of rice genotypes. Proceedings of Papers XXIV Meeting "Faculty with Farmers" '99, Vol. 7, 47-56. Skopje.

[11] Ilieva Verica, Andreevska Danica, Andov D., Najčevska Cvetanka (2005/2006): Some more significant character- 
istics of the new created rice varieties Prima riska and Montesa (Oryza sativa L.). Yearbook of the Institute of Agriculture, Skopje, Vol. XXIV/XXV, 51-59. Skopje.

[12] Милев В. (1968): Проучуавания вьрху растения. Pеnродуктивни особености и условляване на технологи- ческите качества на одглядувани у нас оризове сортове. Пловдив.

[13] Rutger, J. N. and Qualset, C. O. (1972): Plant breeding to increaese protein from cereal crops. California.

[14] Rutger, J. N. (1975): Breeding for increased protein in rice, California. 